\title{
NECTAR THIEVERY BY ANTS FROM SOUTHERN SPANISH INSECT-POLLINATED FLOWERS
}

\section{C.M. HERRERA (1), J. HERRERA (2) and X. ESPADALER (3)}

(1) Estación Biológica de Doñana, Sevilla-12, Spain

(2) Departamento de Botánica, Facultad de Biología, Sevilla-12, Spain

(3) Departamento de Zoología, Universidad Autónoma de Barcelona, Bellaterra, Barcelona, Spain

Reçu le 26 mai 1983.

Accepté le 23 décembre 1983.

\section{SUMMARY}

Correlates of ant nectarivory have been investigated in a sample of 75 insectpollinated, nectar-producing southern Spanish plant species. Ants exploit floral nectar opportunistically. Variation among plant species in sugar secretion rates and flower location relative to ground level do not influence either the chances of ant visitation or the identity of ant species involved. Mechanical restrictions on nectar accessibility (tubular corollas, occlusive structures) decrease nectar thievery. Some evolutionary trends in floral morphology usually related to a decrease in the range of effective pollinators alone may simultaneously be interpreted in terms of increased plant adaptedness to exclude non-pollinating insect nectarivores.

\section{RESUME}

\section{Consommation de nectar par les fourmis sur les fleurs pollinisées} par des insectes du sud de l'Espagne

On a étudié quelques facteurs liés à la consommation du nectar chez les fourmis dans un échantillon de 75 espèces de plantes du sud de l'Espagne qui sont pollinisées par des insectes et qui produisent du nectar. Les fourmis exploitent le nectar de façon opportuniste. La variation entre les espèces de plantes en ce qui concerne le taux de sécrétion de nectar et la localisation des fleurs par rapport au sol n'a pas d'incidence, pas plus que la possibilité de visite par les fourmis ni l'identité des espèces enregistrées. Les restrictions mécaniques à l'accessibilité du nectar (corolles tubulaires, structures fermées) diminuent la consommation de nectar par les fourmis. Quelques tendances évolutives dans la morphologie florale, habituellement liées à une augmentation de la spécificité des pollinisateurs, peuvent être interprétées simultanément en termes de meilleure adaptation des plantes pour exclure des insectes non pollinisateurs qui profitent du nectar. 


\section{INTRODUCTION}

Although they have been occasionally reported as pollinators for some plants (e.g., HickMaN, 1974 ; WYaTt, 1981 ; BRANTJES, 1981), ants most commonly are "undesirable" flower visitors which do not perform pollination (PRoctoR and YeO, 1973 ; FAEGRI and VAN DER PIJL, 1979). Presence of nectar-feeding ants in flowers has been found associated with decreased seed set and pollinator visitation rates (WYATT, 1980; FRITZ and MORSE, 1981). In the terminology of INOUYE (1980), ants behave as "nectar thieves"; while they do not make holes to extract nectar and they enter the openings used by pollinators, a mismatch of morphologies and behaviours precludes pollen movement both among flowers and plants. We present here the results of a regional survey of the occurrence of nectar-feeding ants in flowers of southern Spanish, nectar-producing insect-pollinated plants, documenting the incidence of this ubiquitous group of nectar thieves in a regional flora and analyzing some correlates of ant nectarivory.

The susceptibility of the plant reward to being taken by detrimental organisms has presumably played an important role in shaping the evolution of plant-animal food-mediated mutualisms (e.g., THOMPSON and WILSON, 1978 ; THOMPSON; MCDADE and KINSMAN, 1980; C.M. HerRera, $1982 a$; StePhensoN, 1982). Despite this, disproportionately little work has been done on the actual incidence of "parasites". on mutualisms (sensu JANZEN, 1975), in comparison with the extensive attention received by the interaction of mutualistic organisms (but see JANZEN, 1977; WYATT, 1980 ; YounG, 1980 ; FrITZ and Morse, 1981 ; MCDADE and KinSMaN, 1980 ; GIll et al., 1982 ; RoubiK, 1982). The identification of some ant or plant features associated with nectar thievery may contribute to the understanding of some general aspects of plantpollinator evolutionary interactions.

\section{STUDY AREA AND METHODS}

Information presented in this paper was gathered during 1981-82 as part of more extensive regional studies on the floral biology (J. HERRerA, 1982) and reproductive ecology (C.M. HERRERA, unpubl.) of southern Spanish plants. Data were mostly collected in 12 localities broadly distributed across Andalusia, the southernmost Spanish region (table 1 ). They encompass a broad variety of habitat types, ranging from coastal sclerophyllous scrublands to montane pine forests (1700 m elevation), although most sites are vegetated by various modalities of mediterranean scrub. We are confident that all major habitat types in the region have been sampled. Sites fall into two contrasting elevational groups, lying either in the lowlands of the lower Guadalquivir River valley or at various elevations on any of the two parallel mountain ranges bordering it. Occasional observations and collections were done away from these principal study sites.

Flowers from 116 species belonging to 28 plant families were examined for nectar production following the methods described by J. HerRera (1982). This involved both 


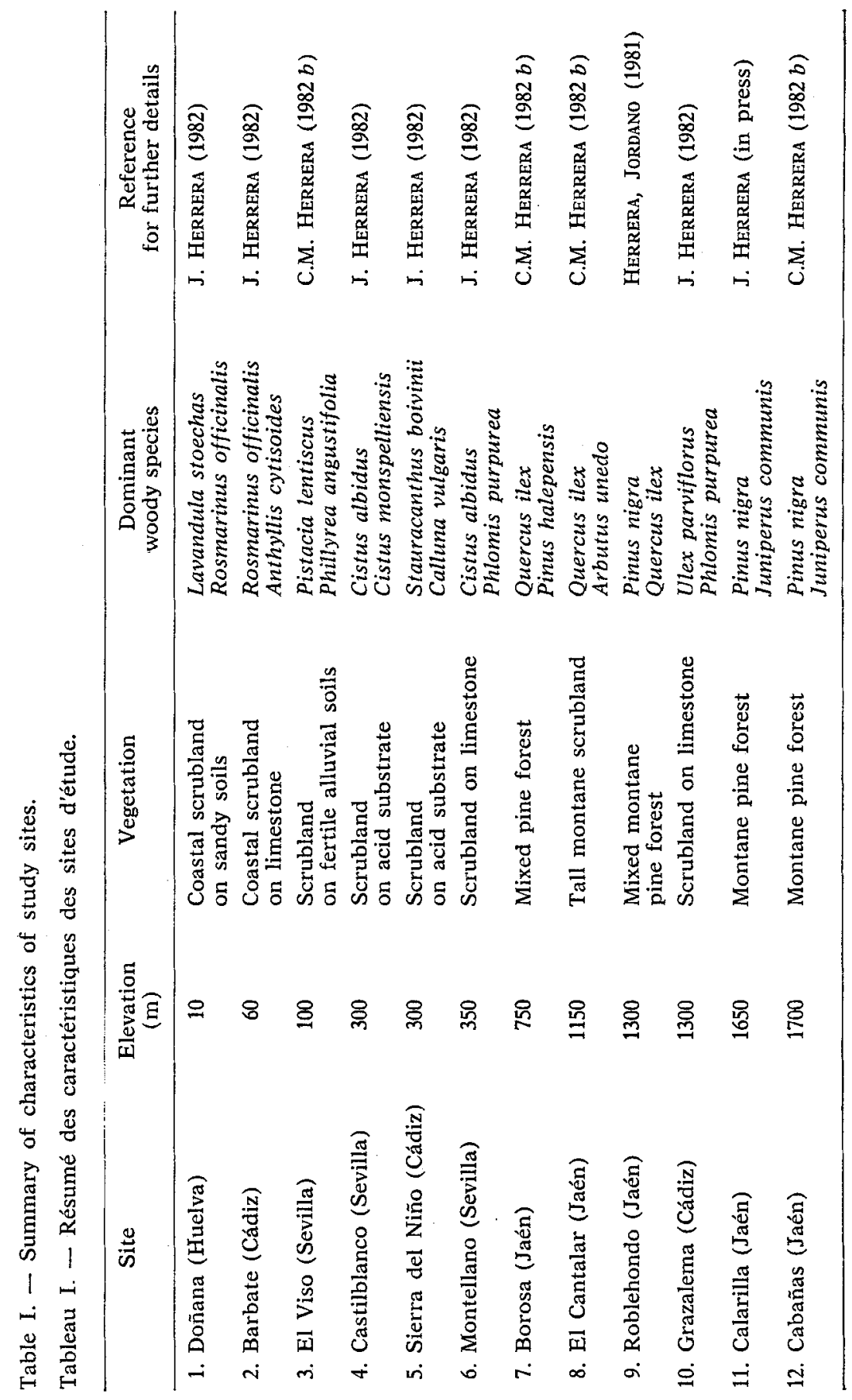


the examination of flowers in the field and the collection of flowering stems, which were kept in closed plastic bags at room temperature and examined for nectar production after $24 \mathrm{~h}$. This procedure permitted ascertaining nectar production in a total of 75 species from 26 families, and this smaller sample (see Appendix for a list of species) will be used here to evaluate differential ant incidence among plant species. Species whose flowers did not secrete nectar have been excluded because, as ants were not observed in nectarless flowers, its inclusion would have artificially decreased ant incidence figures. Herbs constitute $26.7 \%$, shrubs $62.7 \%$, vines $5.3 \%$, and trees $5.3 \%$, of the 75 nectar-producing plant species considered. They mostly flower in spring and early summer, in accordance "with general phenological trends in the region (J. HERRERA, 1982; C.M. HERRERA, in press).

As an indirect estimate of flower size, average dry weight of flowers was obtained for the 75 species considered. Samples of 20-100 individual newly-opened flowers were air-dried to constant weight, weighed to the nearest $0.1 \mathrm{mg}$, and an average figure computed. These data were subsequently used to determine any possible relation between size of flowers and either frequency of ant nectarivory or characteristics of foraging ants observed.

Nectar-feeding ants were collected from flowers whenever observed in the course of field work involving observations and censuses of flower visitors (J. HerRerA, 1982) and/or 'while collecting plant stems for the survey of nectar production or other purposes. In a single instance, ants remained unnoticed until they emerged from flowers held in plastic bags. This case refers to flowers with concealed nectar in which it was impractical to observe actual nectar feeding by ants in the field, and will be discussed below. Maximum head width has been taken as an indirect estimator of ant size. Individual ants collected in flowers were measured and average figures obtained for every species recorded. These data have been used to investigate a possible relation between ant size and floral characteristics. Voucher specimens of ant are at the Departamento de Zoología, Universidad Autónoma de Barcelona; under EN 1 to EN 21, ordered as in Collingwood (1978).

\section{RESULTS}

A summary of ant nectar-feeding records, all localities combined, is presented in table II. Ants belong to the subfamilies Myrmicinae ( 2 genera, 7 species), Dolichoderinae $(1,2)$ and Formicinae $(6,12)$, and were found feeding on nectar in the flowers of $21(28.0 \%)$ of the 75 species examined, and $13(50.0 \%)$ of the 26 families. This represents a conservative estimate of the actual frequency of nectar thievery by ants in the sample of plant species examined. Absence of ants from the flowers of a particular species may simply mean that its use by ants was too infrequent as to have been detected 'with our sampling scheme. In the case of plant species with extended flowering seasons, restricted seasonal activity of ants at flowers (MERLE, 1982) may perhaps have produced some negative records.

That ants found in flowers were actually feeding on nectar and taking a significant amount of it, is supported by the following observations. Typically, ants were immobile, with mouthparts in contact with nectarsecreting structures, for periods of up to several minutes. This indicates that they were not collecting pollen or catching small flower-dwelling insects. Often they showed ostensibly distended abdomens. Almost invariably, flowers 


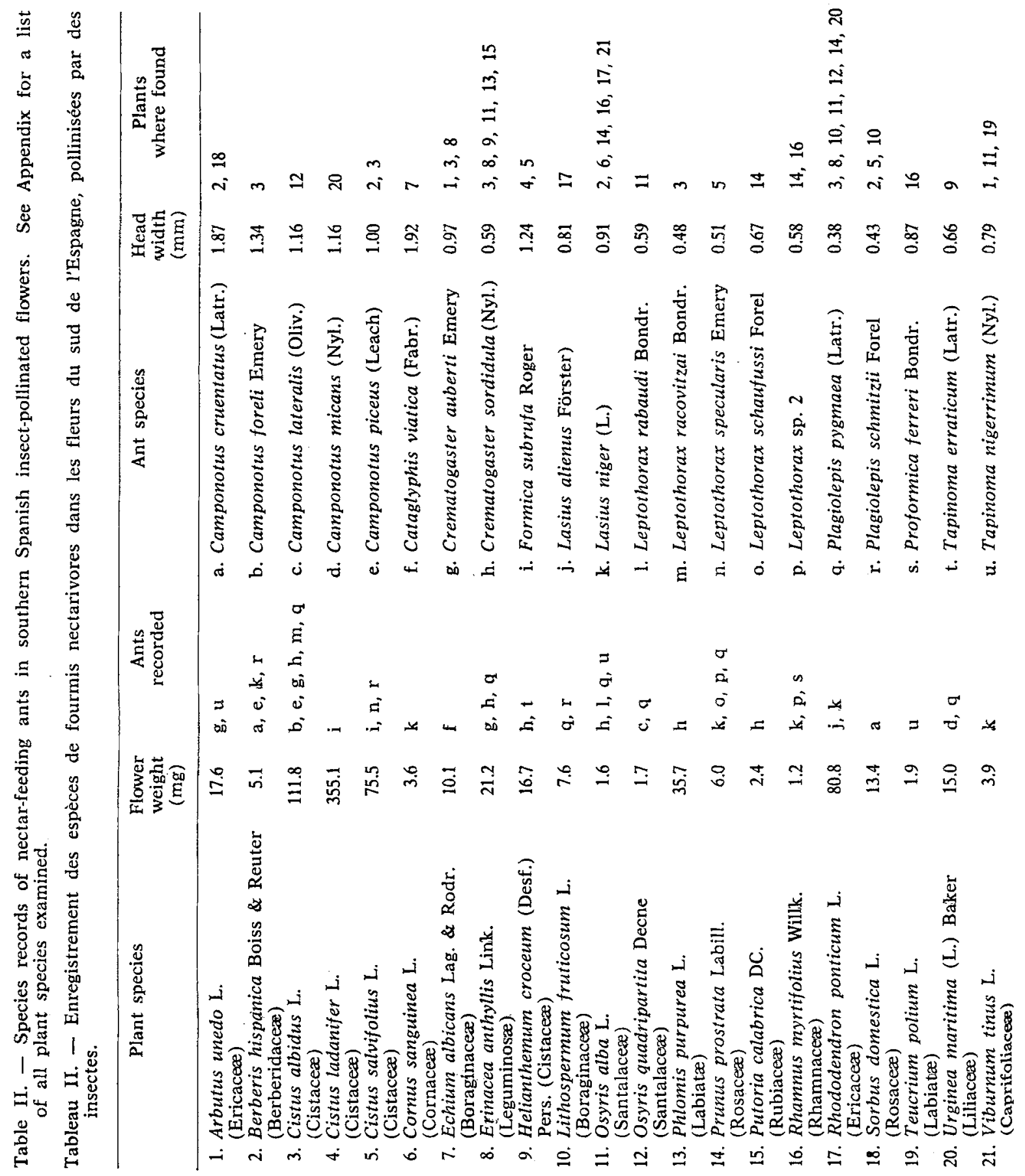


being visited by ants had no nectar, while it most often was present in flowers of the same plant without ants. The ants ordinarily were taking nectar as it was being produced, as suggested by the long periods they spent with mouthparts contacting secretory tissues. Individual ants, even of smallsized species, are able to ingest a significant fraction of nectar production, as illustrated by the results of the following experiment. At the end of a $24 \mathrm{~h}$ period, average nectar volume of 210 Arbutus unedo flowers exposed only to 35 captive individuals of Tapinoma nigerrimum was reduced by a factor of 4.5 as compared to control flowers on the same stems from which ants (and any other visitors) were excluded. All ants had very distended abdomens at the end of the experiment.

By comparing the frequency of occurrence of ants among plant species which differ in some particular floral attribute, it is possible to identify floral traits significantly associated with the presence of nectar-feeding ants. Plant species were assigned to either of two categories relating to the potential accessibility of floral nectar to ants : (a) Concealed nectar; nectar invisible from the exterior, flowers with fused petals and tubular corollas, or papilionaceous structure (48 species); (b) Exposed nectar; disc-bowl shaped flowers with free petals, nectar readily accessible (27 species). Ants were recorded in $14.6 \%$ of species with concealed nectar, and in $51.9 \%$ of those with exposed nectar, and the difference is statistically significant (Chisquare $=11.91, P=0.0006$ ). The probability of recording nectar-feeding ants was therefore about three times higher among species with open corollas and exposed nectar relative to those with tubular or papilionaceous corollas and concealed nectar. Nectar-feeding ants could in some instances have remained unnoticed in the field in closed-corolla flowers, as suggested by the case of Erinacea anthyllis, in which ants were detected only after their emergence from flowers on cut stems. Samples of 10 or more flowering stems (bearing 100-500 open flowers) were however collected from all species surveyed and held for one day in closed plastic bags, hence it is extremely unlikely that ants present escaped our attention We thefore conclude that the result shown above is not an artifact of differential detection of ants in flowers of different morphologies, but it rather reveals that flowers of species with exposed nectar are actually visited more than those which have it concealed at the bottom of more or less closed corollas.

Among flowers with concealed nectar, those having tubular, sympetalous corollas (hence excluding papilionaceous ones) often have, at variable positions along the corolla tube, some structure(s) occluding totally or partly the entrance to the tube. These include scales and/or hairs (e.g., Borago, Lavandula, Phlomis) and the stamens themselves (e.g., Daphne, Vinca, Phagnalon). Ants were recorded in $5(23.8 \%)$ of the 21 sympetalous species lacking occlusive structures in the corolla, and in a single species (Phlomis purpurea; 5.3 
$\%$ ) of the 19 which possessed them. In this single instance, ants had been able to successfully trespass the occlusive zone and reach the nectaries. The sample of ant-visited flowers is too small and the observed difference does not reach significance $(P=0.10$, Fisher exact probability test), but these results suggest that, among species with sympetalous flowers, ant presence tends to be preferentially associated with corolla tubes lacking occlusive structures.

It may be hypothesized that, due to potential influences on the foraging efficiency of ants, differences among plant species in the amount of sugar potentially available per flower may influence ant occurrence. A strong, nearly linear positive relation exists across southern Spanish nectar-producing plant species relating daily sugar secretion rate (SR) and average flower dry weight (FW) (J. HERRERA, 1982) $: \log \mathrm{SR}=0.867 \log \mathrm{FW}-1.026(r=0.825$, $n=42$ ). The hypothesis above may be tested by examining wheter ants occur differentially among plants differing in flower size. Average weight of flowers is greater for species where nectar-feeding ants have been recorded $(10.8 \mathrm{mg}$; geometric mean) than for those which did not yield ant records $(4.7 \mathrm{mg}$ ) $(t=2.08, P=0.041$; two-tailed test, log transformed weight data). In the sample considered, flowers with concealed nectar tend to be lighter than those which have it exposed $(t=1.89, P=0.063$; log transformed data), hence suggesting the possibility that differential occurrence of ants among differently-sized flowers might be just an indirect result of the strong pattern of ant occurrence in relation to the type of nectar presentation documented above. Flower weight for species with and without ant records was compared separately for species 'with exposed (11.9 and $7.3 \mathrm{mg}$, respectively; geometric means) and concealed (9,0 and $4.1 \mathrm{mg}$, respectively) nectar and neither of the two comparisons proved significant $(t=1.27, P=0.22 ; t=0.74, P=0.46$; log transformed data, concealed and exposed nectar, respectively). This indicates that ants occur more frequently in large-flowered species just because these tend predominantly to have exposed nectar in the sample of species examined; when nectar presentation is accounted for, the trend of greater ant incidence among large-flowered species is no longer significant. Sugar secretion rates of individual flowers do not appear therefore to influence substantially the probability of ant occurrence when nectar presentation type is held constant.

The total amount of sugar produced per inflorescence is probably of greater significance to foraging ants than the amount produced by individual flowers. A many-flowered inflorescence of small flowers may produce far more nectar than a few large, isolated flowers. The distribution of species with and without records of nectar-feeding ants among classes of flower weight (above and below the median, $5.25 \mathrm{mg}$ ) and inflorescence size ( $\leqslant 5$ and $>5$ flowers) was analyzed by means of a three-way $G$-test of independence (SoKAL and ROHLF, 1969). Flower weight and inflorescence size are significantly related in the 75 -species sample considered $(G=20.2$, 
$P<0.0001$ ), lighter flowers being aggregated into larger inflorescences more often than heavier ones. When the effect of flower weight on ant incidence is removed, presence of ants is significantly related to inflorescence size $(G=116.0, P \ll 0.0001)$, species with larger inflorescences yielding relatively fewer ant-feeding records than those with smaller inflorescences. This may be an indirect result of the relation between ant occurrence and type of nectar presentation shown above, since this latter variable (concealed vs. exposed nectar) is significantly related to inflorescence size ( $G=6.3, P=0.012$ ). Separate analyses of the dependence of ant occurrence on inflorescence size for species with concealed $(G=4.10, P=0.043)$ and exposed $(G=3.4$, $P=0.068)$ nectar reveal that, after accounting for nectar presentation type, a slight trend still exists, ants tending to occur more frequently in species with small inflorescences.

Height above ground of flowers does not have apparently any effect on the frequency of occurrence of ants among surveyed species. The proportion of species with records of nectar-feeding ants is not significantly different for species having flowers mostly below $0.25 \mathrm{~m}(33.3 \%, n=15)$, between 0.25-0.50 m (14.8\%, $n=27)$, between 0.50-1.0 $\mathrm{m}(28.6 \%, n=14)$ and above $1.0 \mathrm{~m}(42.1 \%, n=19)(G=4.58, P=0.21)$.

There is not apparently any relation between the size of individual flowers (as estimated by average dry 'weight) and the size of visiting ants as estimated by maximum head width (fig. 1). We similarly did not find a relation between ant size and flower cross diameter (measured at outermost perianth projection). Ants of any size may be found visiting flowers of any size in the set of species yielding nectar-feeding records. Flowers with concealed and exposed nectar are similar with regard to the size of ants found in them (fig. 1).

\section{DISCUSSION}

Ant species found feeding in nectariferous flowers apparently, represent a haphazard assortment of the southern Spanish ant fauna (see, e.g., Haro and Collingwood, 1977; TINaut, 1981; Fernandez and Rodríguez, 1982). A characteristic of this group of ants is the generalized occurrence (except perhaps in Cataglyphis viatica) of some kind of recruitmant to food (types II and III of foraging strategy ; WILSON, 1971 ; CARROLL and JANZEN, 1973 ; OSTER and WILSON, 1978 ; Möglich, 1979 ; Espadal.ER, unpublished). Since nectar is a predictable food in space, but ephemeral in time (on a given day), recruitment would be the best way to maximize colony food intake. Formicine and Dolichoderine ants have the proventriculus adapted to crop storage of liquids and regurgitative feeding (trophallaxis) (EISNER, 1957). In Myrmicinae the proventriculus is not so elaborated but retains its function as a stomodaeal valve, so there is still the possibility of storing liquid and subsequently feeding it to other colony members. Trophallaxis has been documented for all genera 


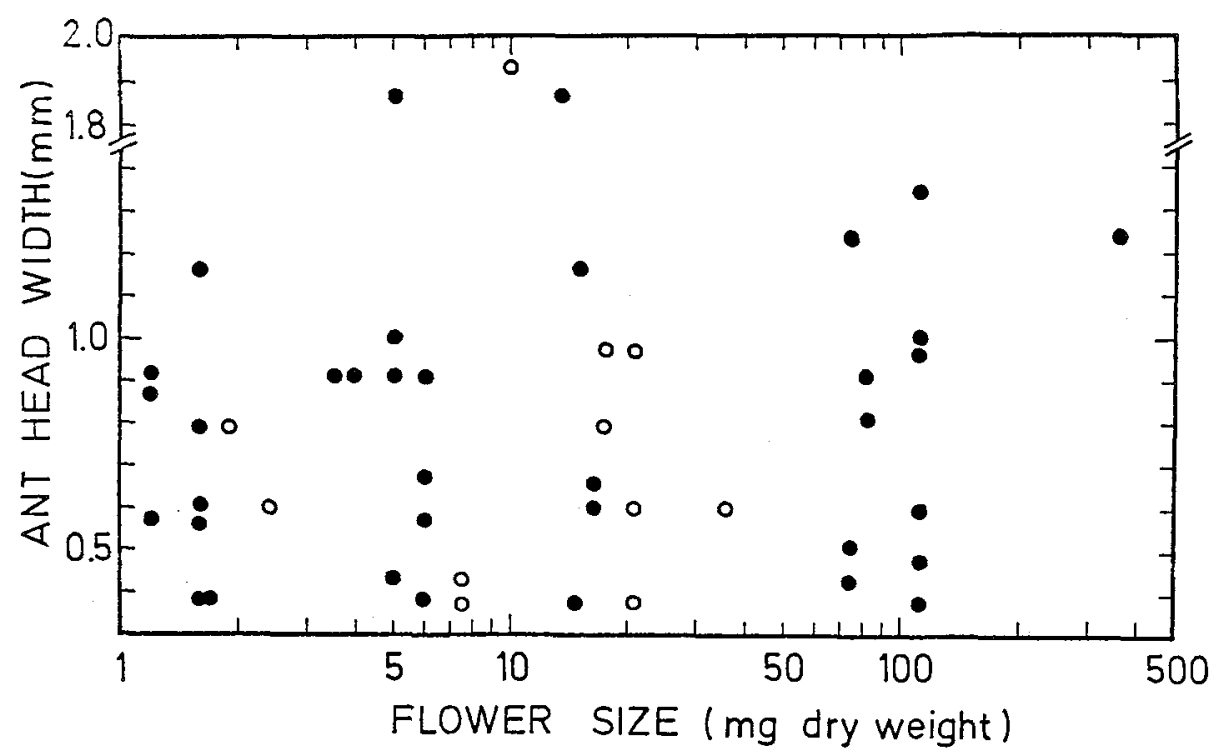

Fig. 1. - There is not any relation between ant size (as estimated by maximum head width) and flower size (dry weight). Each symbol represents a plant-ant species pair (filled symbols, plants with exposed nectar; open symbols, plants with concealed nectar). See table $I I$ for head width and flower weight values of the various ant and plant species.

Fig. 1. - Il n'y a aucune relation entre la taille de la fourmi (évaluée par la largeur maximum de la tête) et la taille de la fleur (poids $\mathrm{sec}$ ). Chaque symbole représente une paire plante-fourmi (symboles pleins, plantes avec du nectar exposé ; symboles vides, plantes avec nectar enfermé). Voir tableau $I I$ pour la largeur de la tête et la valeur du poids des fleurs pour différentes espèces de fourmis et de plantes.

and nearly all species found feeding on nectar in the present study (WILsoN and EISNER, 1957; StuMPER, 1961; WALLIS, 1961 ; Wilson and.FAGEN, 1974 ; LeNoIr, $1979 a, 1979 b$; JaIsson, 1980 ; Bonavita and Gavioli, 1981 ; EsPadaler, unpublished). Food habits of these species are poorly known; some of them have been reported as nectarivores, omnivores or aphid tenders (SoulIE, 1956 ; Baroni URBant, 1968, 1978 ; Du Merle, 1982), but their feeding regimes may vary with habitat type and season (Du MERLE et al., 1978 ; BeNoIs et al., 1978). All these data point to an unspecialized exploitation of floral nectar by ants as a group in the study region, as their correlates (trophallaxis, recruitment behaviour) are of a very generalized nature.

Interspecific variation in flower size, concomitant sugar secretion rate, and height above ground do not influence the chances of ant visitation at the species level. Floral structure does have, however, significant effects on ant incidence at the species level. Plant species with disc bowl-shaped flowers with exposed nectar have records of nectar-feeding ants more frequently than 
those with tubular corollas and concealed nectar. Among the latter, ants were found less often among species possessing some kind of occlusive structure in the corolla tube. These results show that mechanical restrictions on nectar accessibility (and/or detectability) are probably decreasing the chances of thievery by opportunistic ants.

Floral nectar consumption by non-pollinating agents has in most instances a detrimental effect on visitation rates by pollinators and thus may affect adversely reproductive success through reduction in seed set (WYATT, 1980; MCDAdE and KINSMAN, 1980 ; FrITZ and MoRSE, 1981 ; Gill et al., 1982 ; RoubiK, 1982). The ubiquity, general abundance, opportunistic feeding, and recruitment behaviour of ants (CARROLL and JANZEN, 1973) probably make of them outstanding selective agents on plants. This has favoured the evolution of a varied array of "defensive" mechanisms against nectar pilferage. Chemical deterrents in floral nectar or floral tissues (JANZEN, 1977; FEINSINGER and SWARM, 1978 ; GUERRANT and FIEDLER, 1981 ; STEPHENSON, 1981) and extrafloral accessory structures such as bracts, trichomes, sticky belts or nectaries (FAegri and VAN DeR PiJl, 1979; Proctor and Yeo, 1973; Feinsinger and SWARM, 1978; GUERRANT and FIEDLER, 1981) have been ordinarily mentioned as adaptations of plants to reduce the detrimental effects of ants. Floral structure has been shown here to influence also ant visitation of flowers at the species level. Patterns of occurrence of these defensive methods among plant species, as well as their differential effectiveness at excluding ants from flowers, have been not investigated. Nevertheless, the few studies so far conducted mentioned above suggest that (1) plants have several distinct defensive options available and may use them interchangeably; (2) no single method is universally effective against nectar thievery by all kinds of ants; and (3) the various defense methods available to plants are not mutually exclusive, and a plant may use several of these simultaneously to increase floral protection from ants. This would explain (1) the frequent absence of ants from species lacking one particular feature which is known to decrease ant incidence (e.g., nearly $50 \%$ of species with disc bowl-shaped flowers in this study did not yield ant records) ; and (2) its presence in species possessing a particular feature generally decreasing ant incidence (e.g., ants in closedcorolla flowers).

Regardless of the actual selective pressures that have promoted their evolution, intrafloral features that reduce the incidence of nectar thieves (toxic or unpalatable nectar; tubular corollas with occlusive structures) may also reduce the range of types of legitimate flower visitors (pollinators) via morphology- or palatability-mediated increases in plant " selectivity " (MAcIOR, 1971 ; Proctor and Yeo, 1973; StePHenson, 1982). A similar situation occurs among endozoochorous plants, other food-mediated plant-animal mutualism (VAN DER PIJL, 1972) in which seeds of species with toxic fruits (presumably evolved in response to invertebrate destructive agents) are dispersed by a 
narrower range of vertebrate legitimate frugivores than plants with nontoxic fruits (C.M. HERRERA, $1982 a$; SORENSEN, 1983). In this way, defensive mechanisms have as an indirect result a reduction in the number of animal mutualistic counterparts interacting with a particular plant species, thus increasing its relative dependence on individual animal species and, conceivably, enhancing the potential for plant-animal coadaptation. Some evolutionary trends in floral morphology which have been interpreted "as a response to increasingly more sophisticated and reliable pollinators" (CREPET, 1979) may have simultaneously played an important role in improving plant aibility to exclude non-pollinating insect nectarivores.

Acknowledgments. - We are indebted to Juan A. Amat and Manolo Carrión for assistance in the field, and our home institutions and the Comisión Asesora de Investigación Cientifica y Técnica (through a grant to S. Talavera, Departamento de Botánica, Facultad de Biologia, Sevilla) for support. Thanks are due to Daniel JANZEN for helpful comments and suggestions on an earlier version of this paper.

APPENDIX. - Nectar-producing, insect-pollinated southern Spanish plant species considered in this study.

Apocynaceæ: Vinca difformis.

Aquifoliacea: Ilex aquifolium.

Berberidaceæ: Berberis hispanica.

Boraginacee : Borago officinalis, Cerinthe major, Cynoglossum clandestinum, C. creticum, Echium albicans, E. gaditanum, E. plantagineum, Lithospermum fruticosum.

Caprifoliaceæ: Lonicera implexa, L. periclymenum, Viburnum tinus.

Cistaceæ: Cistus albidus, C. crispus, C. ladanifer, C. monspelliensis, C. salvifolius, Helianthemum croceum.

Compositæ: Phagnalon saxatile.

Cornaceæ: Cornus sanguinea.

Crucifer: : Malcolmia lacera.

Cucurbitaceæ: Bryonia dioica.

Dioscoreaceæ: Tamus communis.

Ericaceæ: Arbutus unedo, Erica umbellata, Rhododendron ponticum.

Labiatæ: Ballota hirsuta, Lavandula lanata, L. latifolia, L. stoechas, Micromeria graeca, Origanum virens, Phlomis crinita, $P$. purpurea, Rosmarinus officinalis, Teucrium fruticans, T. polium, T. scorodonia, Thymus baeticus, T. capitatus, T. granatensis, $T$. mastichina, $T$. tomentosus, $T$. vulgaris.

Leguminosæ: Anthyllis cytisoides, A. tejedensis, Astragalus lusitanicus, Erinacea anthyllis, Lotus creticus, Lygos sphaerocarpa, Psoralea bituminosa.

Liliaceæ: Asphodelus aestivus, A. ramosus, Scilla peruviana, Smilax aspera, Urginea maritima.

Oleaceæ : Jasminum fruticans.

Primulaceæ: Coris monspelliensis.

Ranunculaceæ: Helleborus foetidus.

Rhamnaceæ: Rhamnus myrtifolius, R. lycioides.

Rosaceæ: Crataegus monogyna, Prunus prostrata, Sorbus domestica.

Rubiaceæ: Putoria calabrica.

Rutacex: Ruta graveolens.

Santalaceæ: Osyris alba, 0 . quadripartita.

Scrophulariaceæ: Antirrhinum majus, Scrophularia sambucifolia. 
Thymelæaceæ : Daphne gnidium, D. laureola.

Umbelliferæ: Bupleurum spinosum.

\section{References}

Baroni Urbani C., 1968. - La fauna mirmecologica delle isole maltesi ed il suo significato ecologico e biogeografico. Antl. Mus. Civ. St. Nat. Genova, 77, 408-559.

BARONI URBANI C., 1978. - Analyse de quelques facteurs autécologiques influençant la microdistribution des fourmis dans les îles de l'archipel toscan. Bull. Soc. Ent. Suisse, 51, 367-376.

Benois A., Merle P. Du, Lafont J.P., Marro J.P., 1978. - L'activité oophage de la myrmécofaune dans différents milieux du Mont Ventoux. Ann. Zool. Ecol. Anim., 10, 205-219.

Bonavita A., Gaviol I M. 1981. - Les inversions du sens du flux alimentaire au cours d'un même contact entre deux ouvrières chez la fourmi Camponotus vagus Scop. (Hymenoptera, Formicidæ). Ins. Soc., 28, 321-340.

Brantues N.B.M., 1981. - Ant, bee and fly pollination in Epipactis palustris (L.) Crantz (Orchidaceæ). Acta Bot. Neerl., 30, 59-68.

CARRoll C.R., JANZEN D.H., 1973. - Ecology of foraging by ants. Ann. Rev. Ecol. Syst, $4,231-257$.

Collingwood C.A., 1978. - A provisional list of Iberian Formicidæe with a key to the worker caste (Hym., Aculeata). Eos, 52, 65-95.

CREPET W.L., 1979. - Insect pollination: a paleontological perspective. Bioscience, 29, 102-108.

EISNER T., 1957. - A comparative morphological study of the proventriculus of ants (Hymenoptera: Formicidæ). Bull. Mus. Comp. Zool. Harvard, 116, 439-490.

FAEGRI K., VAN DER PIJL L., 1979. - The principles of pollination ecology. 3rd ed., Oxford, Pergamon Press.

FEINSINGER P., SWARM L.A., 1978. - How common are ant-repellent nectars ? Biotropica, $10,238-239$.

FERNANDEZ J, RodRíguez A., 1982. - Les peuplements de fourmis dans la Sierra Morena centrale (Espagne). Rapports avec l'exposition et la végétation. Ins. Soc., 29, 358-368.

FRITZ R.S., MORSE D.H., 1981. - Nectar parasitism of Asclepias syriaca by ants : effect on nectar levels, pollinia insertion, pollinaria removal and pod production. Ecologia (Berl.), 50, 316-319.

GILL F.B., MACK A.L., RAY R.T., 1982. - Competition between hermit hummingbirds Phætorninæ and insects for nectar in a Costa Rican rain forest. Ibis, 124, 44-49.

Guerrant E.O., Fiedler P.L., 1981. - Flower defenses against nectar-pilferage by ants. Biotropica, 13, 25-33.

Haro A. de, Collingwood C.A., 1977. - Prospección mirmecológica por Aṇdalucía. Bol. Est. Centr. Ecol. Madrid, 6, 85-90.

Herrera C.M., 1982 a. - Defense of ripe fruits from pests: its significance in relation to plant-disperser interactions. Am. Natur., 120, 218-241.

HerRera C.M., $1982 b$. - Seasonal variation in the quality of fruits and diffuse coevolution between plants and avian dispersers. Ecology, 63, 773-785.

Herrera C.M., in press. - Escala espacial y evolución de los mutualismos plantadispersante : estudios en la Sierra de Cazorla. Actas I Sem. Res. Biosfera, La Rábida, Huelva, Spain.

Herrera C.M., Jordano P., 1981. - Prunus mahaleb and birds: the high-efficiency seed dispersal system of a temperate fruiting tree. Ecol. Monogr., 51, 203-218.

Herrera J., 1982. - Introducción al estudio de la biología floral del matorral andaluz. Thesis, Univ. Sevilla, Spain.

Herrera J., in press. - Vegetación del Valle del Guadahornillos (Sierra de Cazorla, Jaén). Studia (Ecol.

HickManN J.C., 1974. - Pollination by ants: a low-energy system. Science, 184, 1290-1292.

INOUYE D.W., 1980. - The terminology of floral larceny. Ecology, 61, 1251-1253.

JAISson P., 1980. - Les colonies mixtes plurispécifiques: un modèle pour l'étude des fourmis. Biol.-Ecol. Méd., 7, 163-166. 
JANZEN D.H., 1975. - Pseudomyrmex nigropilosa: a parasite of a mutualism. Science, $188,936-937$.

JANZEN D.H., 1977. - Why don't ants visit flowers ? Biotropica, 9, 252

LENOIR A., $1979 a$. - Le comportement alimentaire et la division du travail chez la fourmi Lasius niger. Bull. Biol. France Belgique, 113, 79-314.

LENOIR A., $1979 \mathrm{~b}$. - Feeding behavior in young societies of the ant Tapinoma erraticum : trophallaxis and polyethism. Ins. Soc., 26, 19-37.

MacioR L.W., 1971. - Co-evolution of plants and animals - Systematic insights from plant-insect interactions. Taxon, 20, 17-28.

MCDADE L.A., KINSMAN S., 1980. - The impact of floral parasitism in two neotropical hummingbird-pollinated plant species. Evolution, 34, $944-958$.

Merle P. Du, 1982. - Fréquentation des strates arbustive. et arborescente par les fourmis en montagne méditerranéenne française. Ins. Soc., ¿29, $422-444$.

Merle P. Du, Jourdheurl P., Marro J.P., Mazet R., 1978. - Evolution saisonnière de la myrmécofaune et de son activité prédatrice dans un milieu forestier: les interactions clairière-lisière-forêt. Ann. Soc. Ent. France (N.S.), 14, 141-157.

MöGlich M., 1979. - Tandem calling pheromone in the genus Leptothorax. J. Chem. Ecol., $5,35-52$.

OSTer G.F., WiLson E.O., 1978. - Caste and ecology in the social insects. Princeton, Princeton Univ. Press.

PRocror M., Yeo P., 1973. - The pollination of flowers. London, Collins.

RoubIK D.W., 1982. - The ecological impact of nectar-robbing bees and pollinating hummingbirds on a tropical shrub. Ecology, 63, 354-360.

SoKal R.R., RoHLF F.J., 1969. - Biometry. San Francisco, Freeman.

SORENSEN A.E., 1983. - Taste aversion and frugivore preference. Fcologia (Berl.), 56, $117-120$.

SOULIÉ J., 1956. - La nidification chez les espèces françaises du genre Crematogaster Lund. (Hym. Formicoidea). Ins. Soc., 3, 93-105.

Stephenson A.G., 1981. - Toxic nectar deters nectar thieves of Catalpa speciosa. Am. Mid. Natur., 105, 381-383.

STEPHENSON A.G., 1982. - Iridoid glycosides in the nectar of Catalpa speciosa are unpalatable to nectar thieves. J. Chem. Ecol., 8, 1025-1034.

STUMPER R., 1961. - Radiobiologische Untersuchungen über den sozialen Nahrungshaushalt der Honigameise Proformica nasuta (Nyl.). Naturwiss., 48, 735-736.

ThompSon J.N., 1981. - Elaiosomes and fleshy fruits: phenology and selection pressures for ant-dispersed seeds. Am. Natur., 117, 104108.

Thompson J.N., Willson M.F., 1978. - Disturbance and the dispersal of fleshy fruits. Science, 200, 1161-1163.

Tinaut A., 1981. - Estudio de los formícidos de Sierra Nevada. Thesis, Univ. Granada, Spain.

VAN DER PIJL L., 1972. - Principles of dispersal in higher plants. 2nd ed., Berlin, SpringerVerlag.

WALLIS D.I., 1961. - Food-sharing behaviour of the ant Formica sanguinea and Formica fusca. Behaviour, 17, 17-47.

WrLson E.O., 1971. - The insect societies. Cambridge, Belknapp Press.

WILSON E.O., EISNER T., 1957. - Quantitative studies of liquid food transmission in ants. Ins. Soc., $4,157-166$.

WILSON E.O., FAGEN R., 1974. - On the estimation of total behavioral repertoires in ants. J. N.Y. Ent. Soc., 83, 106-112.

WyatT R., 1980. - The impact of nectar-robbing ants on the pollination system of Asclepias curassavica. Bull. Torrey Bot. Club., 107, 24-28.

Wyatr R., 1981. - Ant-pollination of the granite outcrop endemic Diamorpha smallii (Crassulaceæ). Am. J. Bot., 68, 1212-1217.

Young A.M., 1980. - Nectar robbing of "' four-o-clocks", Mirabilis jalapa (Nyctaginacea) by the social 'wasp Epipona guerini (Vespidæ). Biotropica, 12, 222. 